\title{
A MODEL OF THE PREVENTIVE RESTORATION OF ARCHITECTURAL STRUCTURES BY STEEL AND GLASS
}

\section{A B S S T R A C}

The paper proposes a design concept of seismic resistant architectural structures by using unconventional materials laminated glass and laminated klirit, materials that are not usually used in construction design for that purpose, although being widespread and easily available, and therefore defined as unconventional, with the goal of the preventive restoration. In the proposed design concept, laminated glass and laminated klirit are considered as a filling in a steel frame on which they overlap by the intermediate rubber layer, thereby forming a composite assembly. In this way, vertical elements of stiffening are formed, capable for reception of seismic force and integrated into the structural system of the building. The applicability of such a system was verified by experiments in laboratory conditions where the experimental models based on laminated glass and laminated klirit had been exposed to the cyclic loads that simulate the seismic force. In this way, the load capacity of composite assemblies was tested for the effects of dynamic load that was parallel to assembly plane.

\section{Jefto Terzović}

University of Belgrade - Faculty of Architecture

KEY WORDS

Rastislav Mandić

University of Belgrade - Faculty of Civil Engineering

PREVENTIVE RESTORATION

LAMINATED GLASS / KLIRIT

SEISMIC STIFFENING

LABORATORY TESTING

COMPUTER ANALYSIS 


\section{INTRODUCTION}

The research presented in this paper contributes to the design of seismically resistant architectural objects, defining the concept of seismic bracing by laminated glass/klirit, framed in a steel frame. The concept involves the formation of an effective composite assembly, in which each of the elements of the assembly plays a role in receiving and treating the seismic force. Filling (laminated glass/laminated klirit) accepts a large part of the seismic force and reduces deformation of the structure of the entire structure, the steel frame frames the stiffening system and integrates it into the global structural system of the building, and the rubber performs the function of shock performing (damping). Such a solution could be very applicable where no other intervention is possible, in the sense of the obligation to preserve the aesthetic values of the building, where it is primarily thought of cultural and historical monuments, or to any type of building under some kind of protection. Then, it is possible to convert the existing surfaces with glass - from the function of space separation, to the function of constructive load, or, possibly, new (bearing) surfaces of glass/ klirit can be introduced. This means that the secondary non-wearing elements become bearable. The whole procedure is a model of preventive restoration of an architectural object, which is provided in advance with an impact that could cause damage to it and to which it is sensitive.

\section{THE USE OF UNCONVENTIONAL MATERIALS FOR RECEIVING SEISMIC FORCES}

The glass is characterised as an extremely brittle construction material, which does not have a plastic deformation capability. According to the established design and engineering practice, in the construction structures, in comparison with other traditional building materials, it is not often used as a supporting material. The glass is mainly used as a façade constructive element, which, regarding loads, most often receives only the effect of the wind, at right angles on its plane. For this reason, it can be said about glass as an unconventional material - it is not used only in the traditional way, but it is intended for a completely new role.

The glass has favorable physical and mechanical characteristics, especially in terms of compressive strength, even in terms of tensile strength. The modulus of elasticity of glass is up to two and a half times greater than the modulus of elasticity of concrete of standard quality. 
The decisive feature of glass, which qualifies it for massive use in construction, is transparency, so glass is a very often crucial motive in architectural design and organisation of architectural space. Transparency opens the way of applying the glass in any place in the construction of an architectural object. In this paper, the possibility of using glass for the purpose of receiving dynamic (seismic) forces was explored.

Past testing of glass for the purpose of its possible unconventional use, mainly related to the exposure of the impact to the plane of the glass panel, which simulates the effect on the glass as a security partition. In addition, glass is increasingly seen in the construction industry as a linear bearing element, exposed on bending, especially in the context of special interiors finishing.

Most regulations treat the glass as a nonconstructive element. The glass facade (or individual glazed surfaces) is traditionally analysed as a nonconstructive element in the global sense. The dimensioning of the glass facade is primarily done for its own weight, then for connection with the basic carrier structure, as well as on the effect of the wind that is at right angles on the surface of the panel.

Large damage caused by earthquakes on glass surfaces, initiated studies of the behaviour of glass facades in this area - in case of seismic effects. In general, the research goes in two directions:

- Ensures that damage is minimised on the glass surface itself;

- Includes the glass surface in the load capacity of the structure on seismic load. In this case, the glass surface can participate in the stabilisation of the façade system, or the whole system, on horizontal influences. Such researches are smaller than those dealing with minimisation of damages on glass surfaces.

Sucuoglu and Valaban ${ }^{1}$ deal with the impact of seismic on the glass façade and on individual panels. The behaviour of glass fill both in case of the force effect in the plane and at right angles of the plane of the glass surface are analysed. The mechanism of the behaviour of the glass panel at its level was observed in the intermediate deflections: deformation of the frame that causes the contact panels and frames, rotating the mode (rotation of the panel), which leads to the formation of the pressed diagonal. On the basis of interim displacements obtained on the basis of the equivalent static load, an estimate of the required gap between the panel and the frame was obtained in order not to break the glass. Analysing behavior of glass panels under seismic loading is analysed more for the case of the force at right angles on the plane, as the plate is supported by pinned joints on the periphery. 
Huveners, F. van Herwijnen, F. Soetens, and H. Hofmeyer, ${ }^{2}$ experimentally analysed the possibility of mobilising glass panels in order to stabilise the entire steel facade. The load is viewed as static. Experimentally analysed an isolated circuit in the plane: the bearing capacity of the steel frame with joints and glass panels. The influence of different types of connections (from epoxy and polyurethane) with different modes of supporting is tested - direct front supporting, side lateral and lateral one-sided. For the first type of connection, the formation of a pressed diagonal was observed, similar to the previous paper mentioned.

Chiara Bedon and Claudio Amadio ${ }^{3}$ are concerned with the problem of buckling glass panels under the load in their plane. Stability of glass panels is an important moment in the analysis of glass panels loaded in the plane.

In the paper authored by Krstevska, Taškov and Rajčić, ${ }^{4}$ the glass panels are used to stabilise the wooden frames. The connections between panels and frames are based on epoxy, silicone or polyurethane. Experimental and numerical research (Finite Element Method - FEM) was conducted. Panel and frame interaction has been shown to be crucial for overall rigidity and load capacity. For epoxy bonding, it was found to be rigid and provide a full composite bond between the frame and the glass panel. Load capacity is large, and ductility is small. With polyurethane (or silicone) adhesives, it is completely different. Relatively rapidly the load is exceeded by the tension of the adhesive and the distortion of the composite bond, so the load capacity is considerably lower.

Štrukelj, Ber and Premrov, ${ }^{5}$ were engaged in dynamic experimental research of wooden frames with glass fillings. This is one of the few papers under which dynamic testing was conducted. The main source of energy dissipation is sliding between the glass panels and the wooden frame, as well as in the hinges of the wood frame itself.

In addition to glass, from the aspect of transparency, plastic polymers are also interesting, primarily polycarbonates and polymethyl methacrylate, which are widely known in everyday practice by the names of specialised manufacturers (for example, klirit). The degree of transparency of these materials is at least equal to the degree of transparency of the glass, and may even be higher. At the same time, the polycarbonate elasticity modulus is extremely low and its value is about one tenth of the value of the elasticity standard of standard quality concrete, that is, about one-twentieth of the modulus of elasticity of glass. However, due to their transparency, polycarbonates and polymethyl methacrylate are generally applicable in architectural objects and the behaviour 
of polycarbonate and the research on polymethyl methacrylate behaviour to the effect of dynamic (seismic) loading is necessary.

The aesthetic quality of glass and certain types of polycarbonate and polymethyl methacrylate, which are primarily reflected in their transparency, makes them very desirable materials from the design aspect, which contributed to the formation of the basic idea for the potential use of both glass panels and polycarbonate and polymethyl methacrylate (clearing) for the purpose of receiving seismic forces.

This paper examines the possibility of using structural glass and klirit as materials for securing architectural objects from the effects of seismic forces in the form of vertical panels. For this purpose, the behavior of the panel of the structural glass and klirit to the effect of a force that is parallel to its plane is examined as a priority.

According to the concept of aseismic stiffening of architectural objects using the glass and klirit, which is exposed in this paper, both panels of the structural glass and klirit, whose role is the reception of forces acting parallel to its plane, is rounded up in the metal (steel) frame. The filling of glass, or klirit, rests on the steel frame through a hard rubber. Accordingly, a panel based on structural glass or klirit is a composite constructive assembly composed of three different materials - fillings (glass/clitter), rubber and steel - which have different physical-mechanical characteristics, as well as different thermal coefficients of linear expansion, so the object of the proposed research also is the joint operation of these three materials under the influence of static and dynamic load.

Essentially, the glass can be considered as an ideal brittle material. The breakdown of the glass element is always performed suddenly, at a moment, with the flashing crack propagation along the entire dimension of the element.

The proposed topic of the research examines the possibility of the maximum use of the physical and mechanical characteristics of the glass before the formation of a broken fracture, since the brittleness - as the basic disadvantage of the glass - defines the limit of the problem of the proposed research topic.

The panels are made of structural glass or klirit, which is part of the composite assembly and is the subject of the proposed research topic and itself represents a package (laminated panels). The panel of glass or klirit, as part of a wider composite assembly, is a laminate structure, because it is composed of several individual layers - lamellas $-4,6,8$ or $10 \mathrm{~mm}$ thick, which are interconnected 
by special chemicals. The final thickness of the glass or klirit package can be $60,80,100 \mathrm{~mm}$, which depends on the technology of the manufacturer and the design stresses. The connection of individual lamellas to a compact product package is a special issue and is the subject of a series of research, both in terms of technology and application of adhesives, and in terms of behavior under load.

In the part dealing with glass, the subject of research is a standard construction float glass and in the sense of determining the physical and mechanical characteristics and in order to assess the possibilities of use as a structural material for receiving dynamic load. The intention is to check the behaviour of widely available material, so usually float glass is selected.

In addition to the basic type of glass, the subject of research is a transparent plastic mass, for which in practice the most commonly used colloquial name is Klirit, according to the nomenclature of a specialised manufacturer. This material, in aesthetic sense, possesses the same qualities as glass, which imposes it as a possible solution for use in load-bearing structures of architectural objects. As was done in the case of glass, it was tested as a standard quality material, also widely used.

The first phase of laboratory testing was carried out in the laboratory, when experimental samples - test specimens and prisms of two materials (glass and klirit) - were exposed to the effect of static loading, with the aim of determining the physical and mechanical properties of the material.

The second phase of the test, also carried out in laboratory conditions, is an experimental check of the behavior of the experiment object - the basic individual element of the structure - the glass/klirit-based panel, on the effect of the cyclic load applied. In the second phase, test specimens - composite panels - were subjected to the dynamic load by the laboratory equipment. Dynamic load had a certain direction, intensity and frequency - parameters that are defined based on an estimation of earthquake characteristics and possibilities of laboratory equipment.

After laboratory testing, a computational analysis of the possibility of application of the glass/klirit-based system of stiffening was performed, applied on a case study of a particular architectural object. The calculating model of the general constructive system of the building was created, with a special emphasis on the separated mass (subsystem) of the construction, which is sensitive to seismic influences (the dome on eight pillars, at the top of the building). In the first stage of the analysis, by the scientific analytical approach, a computational method 
(A)

(B)

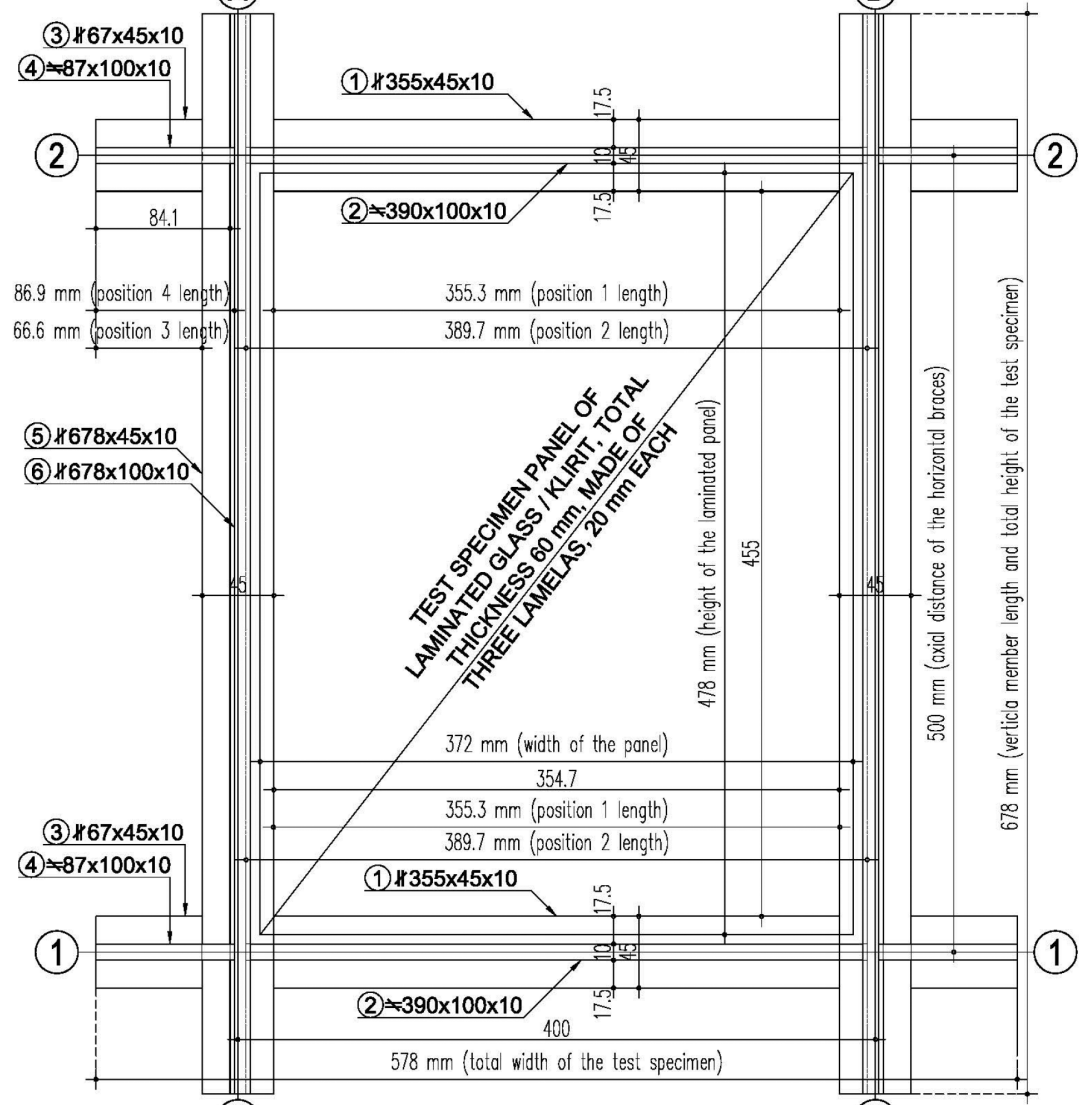

(A)

(B)

Figure 1. A detail - frontal view of the finished composite panel made of laminated glass / klirit ("inside" look)

(3) $\nVdash 678 \times 45 \times 10 \quad$ (A)

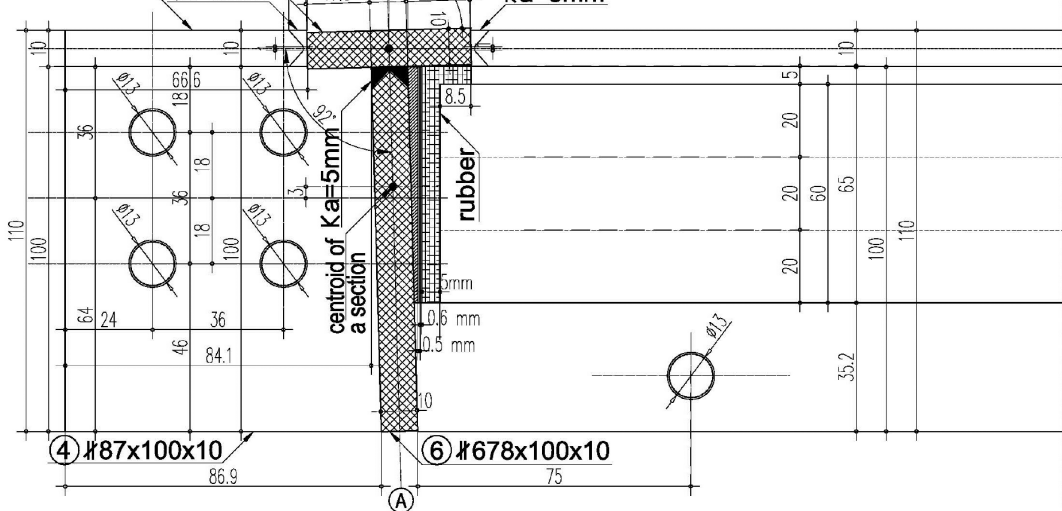

Figure 2. Steel frame construction - detail of the horizontal cross-section: the first phase of installation of laminated glass / klirit panel 
based on the Finite Element Methods, the general constructive system was exposed to the simulated seismic force, in accordance with the valid regulations for designing high-rise buildings in seismically active areas. By analysing the behavior of the general constructive system, the problem of insufficient integration of the separated mass of the structure is identified, which was reflected in the unfavourable results of the modal analysis and the high values of the deformations. In the second stage of the analysis, the elements of aseismic structural stiffening, previously tested in laboratory conditions, were applied to the same computational model. By calculating the structure with the stiffeners and analysing the obtained results, the efficiency of the applied solution was examined. It was found that the stress and deformation results obtained by computational analysis for the individual elements of stiffening, were within the limits of the values obtained in experimental models.

\section{LABORATORY TESTING}

Laboratory tests were carried out on the experimental model of the basic individual structural element, which was materialised from a three-layer laminated glass/klirit with a total thickness of $60 \mathrm{~mm}$, framed by a steel frame, with a layer of hard rubber on the glass/klirit and steel contacts. A total of ten panels were made, of which five panels with laminated glass and five panels with laminated klirit.

The cross section of the steel frame members is in the form of the letter " $T$ " and consists of two steel sheets $10 \mathrm{~mm}$ thick, one of which has a width of $100 \mathrm{~mm}$ (the "rib" of the letter " $\mathrm{T}$ ") and the other has a width of $45 \mathrm{~mm}$ (flange of the letter "T"). The sheets are mutually welded with a $5 \mathrm{~mm}$ thick "K" butt weld, over the entire length of the contact.

The length of the vertical member of the steel frame is $678 \mathrm{~mm}$. The horizontal member of the steel frame has a total length of $578 \mathrm{~mm}$ and consists of three parts (middle part, $355 \mathrm{~mm}$ in length and two end parts, each length $67 \mathrm{~mm}$ ), welded to a vertical member with a $5 \mathrm{~mm}$ thick " $\mathrm{K}$ " butt weld. The length of the middle part of the horizontal member is $355 \mathrm{~mm}$, while the length of the two ends is $67 \mathrm{~mm}$, to which two widths of the vertical member of $45 \mathrm{~mm}$ are added, giving the total length of the horizontal member of $578 \mathrm{~mm}$.

At the ends of the steel frame members, on their ribs, there are four holes $\varnothing 13$ $\mathrm{mm}$, through which the contact of the experimental panel with the laboratory tool is realised. Through the holes $\varnothing 12 \mathrm{~mm}$ pass screw with quality 8.8 , which carry by shear and are accepted by the laboratory tool by two shearing surfaces 
of the cross-section, so they are two sheared. By these holes, i.e. screws, the experimental model was laid on the laboratory tool as well as the application of force to the experimental model.

On the inside, the glass panel is fixed with a steel sheet of a cross-section of the letter "L", through which the screw is mounted in the rib of the vertical or the horizontal of the frame. This allows the full width of the window to be maximised, and in the calculus sense, this will mean that the glass panel is supported by the entire circumference of the hinge. If the flange of the " $\mathrm{T}$ " profile was wider and if the profile on the inside is also wider, the glass panel would be fixed on the extent. ${ }^{6}$

Rubber strip is mounted by the adhesive on the sides - bands - of the panel made of laminated glass or klirit. Through rubber, the panel of laminated glass or klirit is placed on the ribs of horizontal and vertical members. The rubber band has a thickness of $5 \mathrm{~mm}$, a hardness of 75 shores and is reinforced with a textile net in two layers. In terms of durability, the type of rubber must be EPDM (Ethylene Propylene Diene Monomer).

The panel of laminated glass / klirit has a total thickness of $60 \mathrm{~mm}$, and its dimensions are $372 \times 478 \mathrm{~mm}$. The panel is made up of three individual blades $20 \mathrm{~mm}$ thick and all blades are made of float glass (not hardened). The blades are joined into the package by placing a double PVB (Polyvinyl Butyrin) film between the two adjacent blades. The package is then processed in the AUTOCLAV device, in order to obtain adhesion and/or clamping of the lamellas. The lateral surfaces of the panel (bins) of $60 \mathrm{~mm}$ wide, after lamination, must be ideally flat so that the rubber can be glued to them.

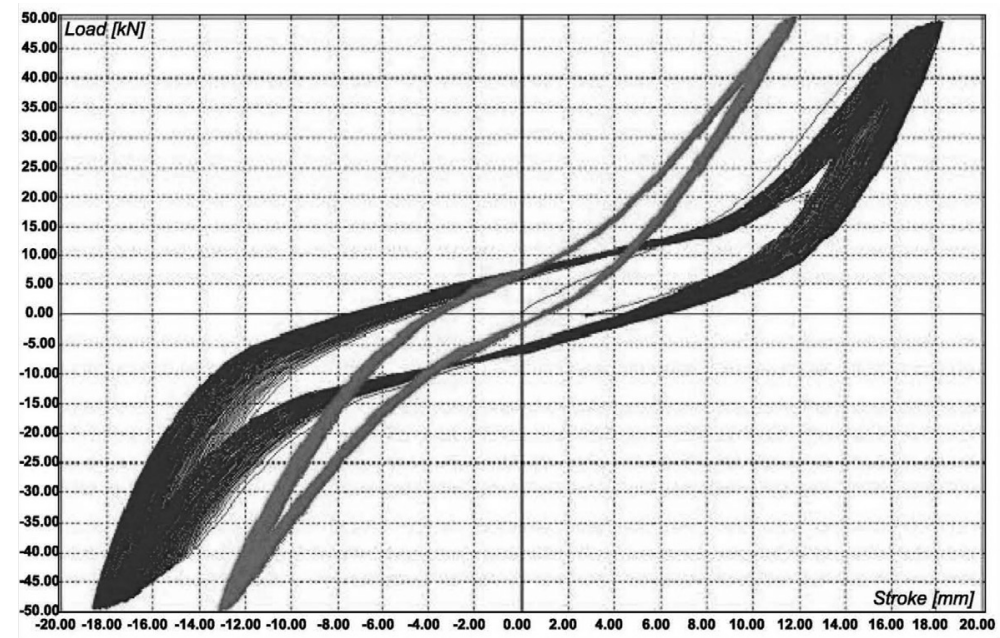

Figure 3 . Hysteresis loops from the testing of glass-filled panels (wider-black) and klirit-filled (narrowgray), subjected to the dynamic force of $50 \mathrm{kN}$ intensity, at a frequency of $1.6 \mathrm{~Hz}$ 
By gluing together the two strips of rubber that touch at the corner of the panel, the way side of one of the tape joining the edge of the frontal surface of the second tape, it is made of structural adhesive. The adhesive must have instant and lasting elasticity, that is, it must not lose elasticity over time. Physicalmechanical properties of the adhesive must be similar to the physical mechanical characteristics of the rubber. The adhesive, with which the rubber strips are nice for the side surfaces of laminated glass panels, must also have instant and lasting elasticity. And with this adhesive, the physical mechanical characteristics must be similar to the physical mechanical characteristics of the rubber.

Dynamic and static tests of the experimental composite panels of both materials (glass/klirit), were performed on a servo hydraulic machine for dynamic and static testing of the last generation ZWICK Roell HB - 250 (Pulzator) material, at the Department of General Mechanical Structures of the Faculty of Mechanical Engineering, University of Belgrade, in the accredited Laboratory Testing Machine Elements and Systems - LIMES (ATS 31-304 SRPS ISO / IEC 17025: 2006, General requirements for the competence of testing and calibration laboratories).

For the needs of the test, a special set of multiple segmental tools is constructed and made, which enables the stability of the test in all three required planes. The tool is constructed in accordance with the test requirements, with increased stiffness, so that its elastic deformations generated during the test do not affect the final results. The positions of assembly and stiffening of experimental models, as well as the points of operation of the main (experimental) load are defined in particular. The connection of the test panels with the tool was achieved using 24 screws of the strength class 8.8.

Dynamic tests were performed in several stages, with forces of $11 \mathrm{kN}, 22 \mathrm{kN}$, $33 \mathrm{kN}$ and $50 \mathrm{kN}$, frequencies of $0.5 \mathrm{~Hz}, 1.6 \mathrm{~Hz}$ and $2.5 \mathrm{~Hz}$ and cycles duration of $30 \mathrm{sec}$ and $60 \mathrm{sec}$.

The Figure 3 illustrates the differences in the behavior of experimental models with filling glass or klirit, subjected to dynamic loading. According to the forms of hysteresis loops in the previous figure, it can be concluded that in the experimental model with a klirit filling, the filling is included earlier in the reception of the force than in the case of a glass-filled model. This anomaly of the glass-filled model is due to the slipping of the fill over the contact surface with the intermedial layer of the rubber, which puts off the load-on-fill time. In this way, the klirit fill shows better integration into the composite assembly of the experimental model. 
It is noticeable that the cyclic force did not immediately reach the maximum value. In the glass filling model, the filler is later included in the force reception, rather than in the model with a clarinet klirit, which is most likely the result of slipping between the rubber and the frame. The moment of reinforcement in the glass model's response is the moment of activation of the pressed diagonal of the fill, which results in an increase in the stiffness of the whole assembly. This effect is observed when exposing an experimental model to a force equal to or greater than $22 \mathrm{kN}$.

Upon reaching the maximum force, the hysteresis loops are generally stable, which means that no systematic degradation of stiffness over time has been noticed. Hysteresis loops in the panel with glass show greater energy dissipation. An increase in energy dissipation per cycle in the glass panel compared to those with a klirit is from $30 \%$ to $80 \%$, and is most likely a consequence of the aforementioned slipping between the intermediate layer of the rubber and the steel frame.

The steel frame shows partial damage on the corners during the test, which in some samples led to a certain drop in stiffness, but not fracture. For most samples, the global response is elastic. The damage at the corners of the steel frame is due to the fact that the welded joint did not show the required toughness in a large number of cycles, which is largely the result of the selected welding technology.

The displacement amplitudes are mostly symmetrical in relation to the mean reference value $x_{0}=\left(x_{\max }+x_{\min }\right) / 2$. The value $x_{0}$ is not always equal to zero, which is the most significant consequence of the conditions for testing or calibrating the equipment. The maximum shifts obtained are for $\mathrm{F}=50 \mathrm{kN}$ about $16 \mathrm{~mm}$, which for the axial height of the assembly $\mathrm{H}=500 \mathrm{~mm}$ gives a relative displacement at the level of the composite assembly $\mathrm{D}=0.032$. For $\mathrm{F}=$ $33 \mathrm{kN}$, this ratio is $\mathrm{D}=0.020$. In the analysed domain, the effect of frequencies on the amplitude of the displacement around the reference value is small.

It was observed that in the investigated domain the part of the force that takes up the fill of the klirit is about $58 \%$ for the amplitude of the force of $11 \mathrm{kN}$, about $60 \%$ for the amplitude of the force of $22 \mathrm{kN}$ and about $67 \%$ for the amplitude of the force of $33 \mathrm{kN}$. The assemblies affect not only the increase in stiffness and load capacity, but also contribute to the increase in damping and additional energy dissipation. 


\section{MODEL OF THE PREVENTIVE RESTAURATION}

For the case study, the building of the National Assembly of the Republic of Serbia in Belgrade was selected. The building is composed of three corps, which constitute one constructive whole together. In the first phase of the computational analysis, a modal analysis was conducted through six tones. In particular, the first two tones can be observed, with a relatively small interval of time difference, and by the analysis of the model has been found to be about the tones of the oscillation of the large dome construction in the basic orthogonal " $\mathrm{X}$ " and " $\mathrm{Y}$ " directions, as shown in the following.

These results show very high values of the displacements of the top of the object caused by the earthquake. It is noticeable that the constructive system of the large dome, due to the action of seismic forces, behaves largely independently and asynchronously in relation to the object of which it is an integral part. It is necessary to find a solution that will shift the movements to an acceptable measure and which will, above all, integrate the constructive system of the big dome into the constructive system of the rest of the object.

The large dome as a reinforced concrete shell, together with the edge ring beam, for the action of horizontal (seismic) forces, represents a significant inertial mass.

The integration of the structure of the large dome with the rest of the structure of the building is achieved by the structural klirit and steel frame. The constructional klirit is installed in the surfaces of the existing glass façade of the large dome, just in place of the existing glass membrane. The existing glass membrane is made in a classic way: a black locksmith of slender profiles forms a net - a grill, or a façade partition, which houses windows of ordinary window glass, with a thickness of 3 to $4 \mathrm{~mm}$.

The concept of structural klirit refers to the klirit that has a bearing role on the facade, and not only the function of partitioning the interior space from the outside, with the assumption of transparency. In this sense, "structural" means carrying, in contrast to the usual meaning in construction or concrete constructions, where a similar word "constructively" is commonly used for non-bearing elements, which are then constructively reinforced.

The construction klirit has a thickness of $d_{s t}=60 \mathrm{~mm}$ and is made of a 400/500 $\mathrm{mm}$ window. The klirit is placed in a steel grill, made up of 9 horizontal crossbars and 11 vertical bars of " $\mathrm{T}$ " cross-section. Each horizontal cross member has 


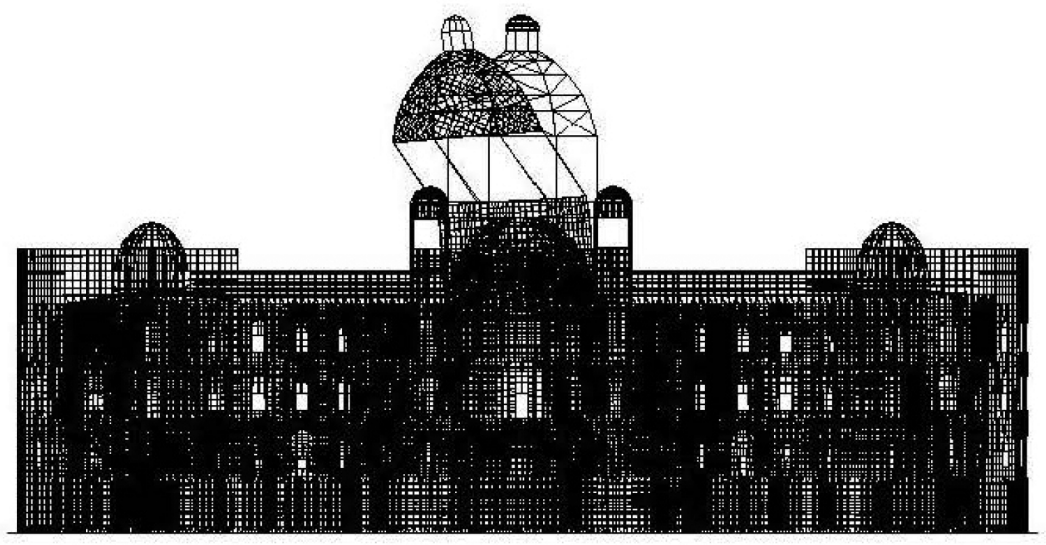

$1 / 6[\mathrm{~T}=0.4780$ сек $/ \mathrm{f}=2.09 \mathrm{~Hz}$

Figure 4. The first oscillation tone - dominant orthogonal " $\mathrm{X}$ " direction

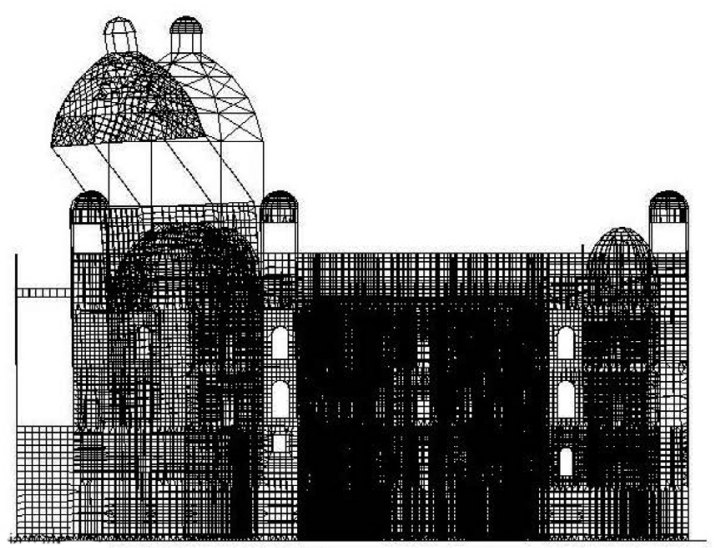

$2 / 6 \Pi=0.4533$ cer $/ \mathrm{f}=2.21 \mathrm{~Hz}]$

Figure 5. The second oscillation tone-dominant orthogonal "Y" direction 
a polygonal longitudinal axis, so that the axis is inscribed in the formidable surface of the transparent facade. Vertical steel barbell grilles are at an axial distance of $\lambda_{\text {ver }}=420 \mathrm{~mm}$, and the horizontal bars are at an axial distance of $\lambda_{\text {hor }}$ $=520 \mathrm{~mm}$. The edges of the steel matrix are rigidly tied to the concrete structure on which they are leaning all their length by being braided by the key, and the keys are at a mutual axial distance $\lambda_{\mathrm{k}}=300 \mathrm{~mm}$.

The described system, made of the steel frame - a matrix - which houses 80 windows of structural klirit, which together make the "mosaic" 4200/4400 $\mathrm{mm}$ in frontal appearance, fills all eight fields between the rectangular crosssectional columns on the large dome facade. Each window of the klirit is rigid in its plane, and through the steel frame, together with the neighboring windows forms a rigid shaped surface, continuously rigidly connected to the existing constructive concrete elements of the big dome. In this way, the construction of the big dome becomes a unique rigid system, composed of:

- the existing concrete structures (eight pillars of rectangular cross-section, ring-shaped beam of rectangular cross-section at the top of pillars at the height of frieze of large dome);

- a steel grill that, according to geometry and division, corresponds to the existing façade of the large dome;

- a structural klirit from rectangular segments, which corresponds to the shape of the existing glass windows on the large dome facade.

In order to determine the effect of introducing elements from a structural laminated glass / klirit into the dome construction, a computational analysis was carried out completely analogous to the previous one. The modal analysis was carried out through six tones.

By comparing the results of the modal analysis of the original computer model with the results from another computer model on which the structural laminated klirit is applied as a stiffening of the constructive system of the large dome, it can be noticed that the properties of the first two tones of the first model moved to the end of the list of tones in the second model.

The conclusion is that by comparing the results of the two modal analyses, it can be noticed that the application of structural laminated klirit in order to stiffen the constructive system of the large dome and its integration into the constructive system of the rest of the object, has achieved a full effect. 


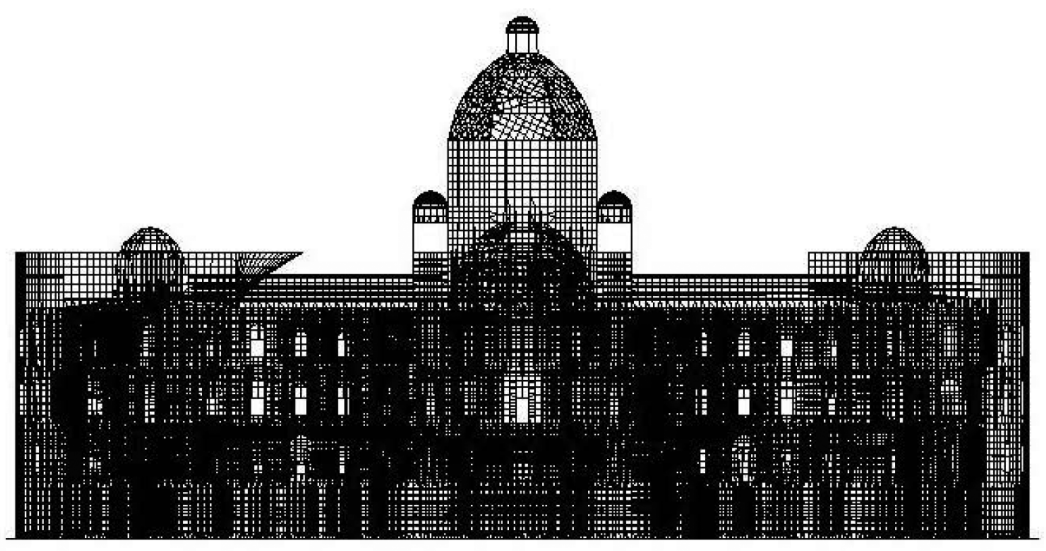

$1 / 6 \Pi=0.3698 \mathrm{cek} / \mathrm{f}=2.70 \mathrm{~Hz}]$

Figure 6. The first oscillation tone -"free" wall at the level of the roof structure, on the left wing of the building (the dome is stiffened)

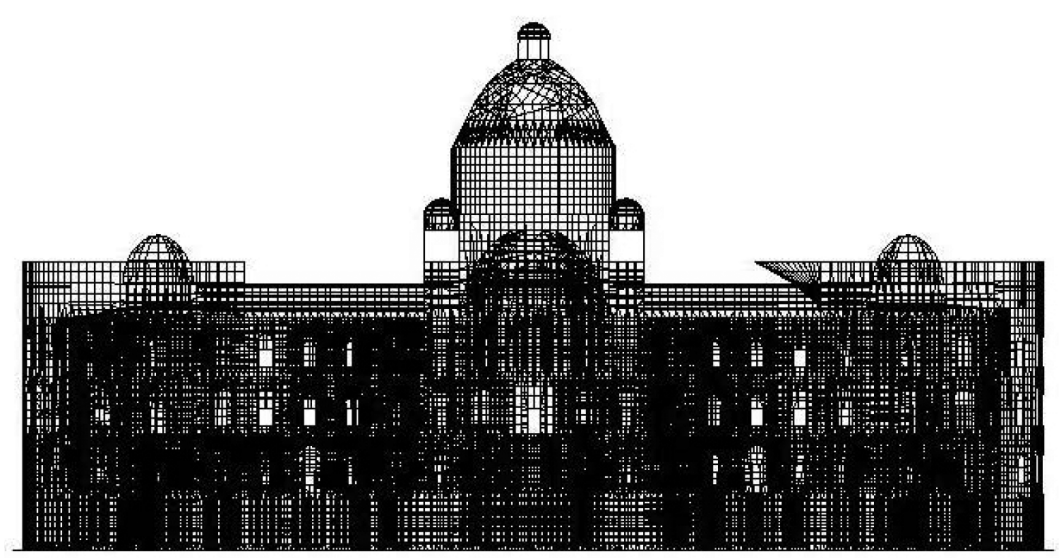

$2 / 6 \Pi=0.2999 \mathrm{ce \kappa} / \mathrm{f}=3.33 \mathrm{~Hz}]$

Figure 7. The second oscillation tone - "free" wall at the roof level construction, on the right wing of the building, similar to the first tone (the dome is stiffened) 


\section{CONCLUSION}

Based on the analysis of the obtained results from the laboratory testing of composite assemblies based on laminated glass and klirit exposed to dynamic loading, it can be concluded that composite assemblies with laminated klirit fillings show:

1. better integration of the fill into the composite assembly;

2. minor shifts in relation to laminated-glass filling sets.

In addition to the formation of a roasting of certain stiffness, the shown composite panels enable the introduction of additional damping into the structural system. The attenuation is primarily realised through the dissipation of energy in the intermodial layer between the filling and the frame, in which the decisive role is played by the rubber, through which the filling (laminated glass/laminated clit) fits on the steel frame. The amortisation or damping function, the intermediate rubber layer achieves by a defined degree of hardness. Laboratory examined experimental models based on lamellar klirit are then presented in a case study through a computer model, as elements of the construction of an architectural object.

The case study was carried out through a complex computer model of object construction, created in a specialised software package, based on the Finite Element Method. In the computer model, the properties of composite panels previously tested in the laboratory, as well as their relationship with other elements of the constructive system of the object, are described through physical-mechanical characteristics and boundary conditions.

The results obtained by the analysis using the computer model show the efficiency of the structural system stiffening with the system of composite panels with a fill from the klirit. The efficiency of the stiffening is, above all, reflected in the form of:

1. the changes in the modal characteristics of the analysed object;

2. reduction of displacements caused by seismic actions.

Seismic analysis is carried out on the basis of equivalent static load, and the obtained forces in structural elements that are created according to experimental models are found within the boundaries of values from laboratory testing. It has been shown that the load capacity of an experimental model, expressed in laboratory conditions, may be sufficient to receive an appropriate part of the seismic force in a realistic construction. 
The analysis of the computer model represents both the initial and final phase in the procedure - the algorithm - designing seismically resistant objects using glass and klirit. In the initial phase, the analysis of the computer model determines the problem, for which a solution is proposed, which, due to the application of unconventional materials, is checked in laboratory conditions. In the final phase, the treatment of the computer model, supplemented by the proposed solution, for which the input parameters are determined by a laboratory test, is continued.

By analysing the computer model, the strength and strain intensities were first and foremost tested according to the criteria that were also defined in the experimental model. The forces and strains are within the limits of the results of laboratory tests. At the same time, the construction is effectively stiffened in terms of changing (improving) the modal characteristics and reducing the deformation.

The analysis of the computer model and laboratory testing in the presented design procedure for seismically resistant architectural objects give a new concept of the application of unconventional materials, primarily for the purpose of preventive restoration, i.e. training for reception of seismic forces, for which these facilities were not originally designed. earthquakes,” Engineering structures Vol. 19, No. 8 (1997): 685-694.

2 E. M. P. Huvernes, F. van Herwijnen, F. Soetens, H. Hofmeyer, "Glass panes acting as shear wall," Heron Vol. 52 (2007): 6-30.

Chiara Bedon and Claudio Amadio, "Buckling of flat laminated glass panels under in-plane compression or shear," Engineering structures 36 (2012): 185-197. Materials Research Vol. 778 (2013): 698-705. 
Amadio, Claudio, Chiara Bedon. "Effect of circumferential sealant joints and metal supporting frames on the buckling behavior of glass panels subjected to in-plane shear loads." Glass Structure Engineering (2015).

Bedon, Chiara and Claudio Amadio. "Buckling of flat laminated glass panels under in-plane compression or shear.” Engineering structures 36 (2012): 185-197.

Huvernes, E. M. P., F. van Herwijnen, F. Soetens, H. Hofmeyer. "Glass panes acting as shear wall." Heron Vol. 52 (2007): 6-30.

Krstevska, Lidija, Taškov, Ljubomir and Rajčić, Vlatka. "Seismic Behaviour of Composite Panel Composed of Laminated Wood and Bearing Glass - Experimental Investigation.” Advanced Materials Research Vol. 778 (2013): 698-705.

Sucuoglu, Haluk and C. V. Girija Vallabhan. "Behaviour of window glass panels during earthquakes.” Engineering structures Vol. 19, No. 8 (1997): 685-694.

Štrukelj, Andrej, Boštjan, Ber, Miroslav, Premrov. "Racking resistance of timber-glass wall elementsusing different types of adhesives." Construction and Building Materials 93 (2015): 130-143. 


\section{MODEL PREVENTIVNE RESTAURACIJE ARHITEKTONSKIH OBJEKATA UPOTREBOM ČELIKA I STAKLA}

\section{Jefto Terzović, Rastislav Mandić}

U radu je predložen koncept projektovanja seizmički otpornih arhitektonskih objekata, upotrebom nekonvencionalnih materijala - lameliranog stakla i lameliranog klirita, u cilju preventivne restauracije. Predloženim konceptom projektovanja, lamelirano staklo i lamelirani klirit, predviđeni su kao ispuna u čeličnom ramu, na koji naležu posredstvom intermedijalnog sloja gume, čime se formira kompozitni sklop. Na taj način se formiraju vertikalni elementi ukrućenja, integrisani u konstruktivni sistem objekta, osposobljeni za prijem seizmičke sile. Primenljivost takvog sistema, proverena je eksperimentom u laboratorijskim uslovima, gde su eksperimentalni modeli na bazi lameliranog stakla i lameliranog klirita izlagani dejstvu cikličnog opterećenja, koje simulira seizmičku silu.

KLJUČNE REČI: PREVENTIVNA RESTAURACIJA, LAMELIRANO STAKLO / KLIRIT, SEIZMIČKA UKRUĆENJA, LABORATORIJSKO ISPITIVANJE, RAČUNARSKA ANALIZA

\section{NEDESTRUKTIVNO ISPITIVANJE DRVETA RENDGENSKIM ZRACIMA Andrej Josifovski, Dijana Savanović}

Rad ispituje mogućnost blagovremenog detektovanja slabih tačaka drvenog konstruktivog sklopa, nedestruktivnim metodama, radi sanacije, pre nego što nastanu njegova vidljiva oštećenja. U tu svrhu korišćeno je rendgensko ispitivanje uzoraka tri vrste drveta: prstensasto poroznih lišćara, difuzno poroznih lišćara i četinara. Pretpostavka je bila da je propusnost drveta za rendgenske zrake obrnuto srazmerna koeficijentu statičke otpornosti drveta. Mehanička svojstva uzoraka drveta korišćenih u radu su aproksimacija njihovih tabelarnih vrednosti koeficijenata statičkog naprezanja drveta izraženih u MPa. Za dokazivanje ovih hipoteza korišćen je rendgen aparat sa opsegom rada od 40-125 kV i $0.50=360 \mathrm{~mA} / \mathrm{s}$ istovetno njegovoj primeni u humanoj medicini. Ovim radom se pokazalo da se rentgenskim zracima može uspešno utvrđivati kvalitativno svojstvo određene vrste drveta, a time i njegova najbolja upotrebljivost, što je na primer, od posebnog interesa za restauraciju i obnovu objekata od kulturnog i istorijskog značaja. Nedestruktivne metode ispitivanja drvenog konstruktivnog sklopa, svakako opravdavaju svoju ulogu na tom polju i nameću zahtev njihovog daljeg usavršavanja. 